\title{
Trophic relationships among fish assemblages on a mudflat within a Brazilian Marine protected area
}

\author{
Dafne Marcelle de Almeida Ramos Campos, Adna Ferreira da Silva, Natalice dos Santos Sales, \\ Ronnie Enderson Mariano Carvalho Cunha Oliveira, Andre Luiz Machado Pessanha*
}

Universidade Estadual da Paraíba.

(Rua Juvência Arruda, Bodocongó, Campina Grande - PB)

*Corresponding author: andrepessanhauebp@gmail.com

\begin{abstract}
The present study deals with the temporal variations in diet and the trophic guilds of dominant fish species on a tidal mudflat during the dry and rainy seasons. We sought to classify the diet composition of 17 species in the Mamanguape river estuary, northeastern Brazil, identifying the dominant food components and evaluating the effects of seasonality on the guild organization. Diets varied little between species and seasons, though they seemed to be more heterogeneous during the rainy season. Five primary feeding guilds were identified, in accordance with the importance of prey in the diets: (1) Detritivore, (2) Zooplanktivore, (3) Zoobenthivore-epifaune, (4) Zoobenthivore-infaune, and (5) Piscivore. Most fishes fed on a diverse range of food items but relied heavily on zooplankton prey. Several fish species showed a tendency to a specialised diet, with almost all species showing some degree of opportunistic feeding. A high degree of diet overlap was found among some species; however, the presence of exploitative competition could not be determined.
\end{abstract}

Descriptors: Diet, Feeding ecology, Fish community, Diet overlap, Estuary.

\section{Resumo}

O presente estudo visa verificar as variações temporais na dieta e nas guildas tróficas nas espécies de peixes dominantes em uma planície de maré, durante as estações seca e chuvosa. A composição da dieta e a organização trófica de 17 espécies foi estudada no estuário do rio Mamanguape, Nordeste do Brasil. Foram identificados os itens dominantes e verificado os efeitos da sazonalidade sobre a organização das guildas. A dieta variou pouco entre as espécies e as estações; durante a estação chuvosa, a dieta das espécies apresentou-se mais heterogênea. De acordo com a importância de presas nas dietas, foram identificadas cinco guildas alimentares principais: (1) Detritívora, (2) Zooplanctívora, (3) Zoobentívora-epifauna, (4) Zoobentívora-infauna, e (5) Piscivora. A maioria dos peixes predou uma variada gama de itens alimentares, mas fortemente baseados em presas do zooplâncton. Alguns peixes apresentaram tendência para uma dieta especializada, com quase todas as espécies mostrando algum grau de alimentação oportunista. Um alto grau de sobreposição de dieta foi encontrado entre as espécies; no entanto, a ocorrência de competição por exploração não foi observada.

Descritores: Dieta, Ecologia alimentar, Comunidades de peixes, Sobreposição alimentar, Estuário. 


\section{INTRODUCTION}

Estuaries are recognised for encompassing a variety of habitats, including mangrove swamps, algal banks, and mudflats (TSE et al., 2008), with vegetated habitats exhibiting greater fish abundance and species richness than non-vegetated habitats (LUGENDO et al., 2006). This pattern is the result of the greater structural complexities and resources that develop on a vegetated substrate, providing greater protection from predators and increased food availability (WANG et al., 2009). This structural complexity increases the availability of consolidated substrates for the diatom colonisation of micro/macro algae that supports great fish diversity (HINDELL; JENKINS, 2004).

However, as non-vegetated habitats, tidal mudflats have been identified as important environments for supporting the estuarine life cycle and are considered to be key habitats for the estuarine food chain because of their high primary productivity when compared with adjacent areas (FRANÇA et al., 2008, 2009). Mudflats are most commonly located at the mouth of estuaries and serve multiple roles, such as transit routes and/or habitats for some fish species in tropical and subtropical estuaries, particularly for juveniles and school-forming species (HINDELL; JENKINS, 2004; BARLLETA; BLABER, 2007), while the use of structured areas, such as mangrove swamps, has been suggested for small specimens, such as the Gobiidae (HINDELL; JENKINS, 2004).

The loss of these intertidal areas, due to the constant demands of human activities in coastal areas, is a globalscale problem (ROPER et al., 1988; BOER; PRINS, 2002; MARTINHO et al., 2007; TSE et al., 2008; FRANÇA et al., 2012). On tidal mudflats, fish find refuge near the coast; thus, these habitats are considered to be additional recruitment areas that are essential for the life cycle of these fish species. However, contradictions exist, creating the need to study tidal mudflats independently to better understand how resources are used by different fish species, especially by juveniles.

In northeastern Brazil, river runoff is strongly influenced by seasonal rainfall. Interannual and seasonal variability in river flows can cause changes in the circulation and physicochemical conditions of the estuary. Changes in salinity can affect several variables, from the submerged vegetation in tidal channels to the diversity of benthic organisms and fish. Salinity affects fish distribution in estuaries through its influence on food availability (VIVIER et al., 2010). Few studies have incorporated temporal heterogeneity when examining trophic structures, despite its apparent relevance for the structure and function of fish assemblages (WILSON; SHEAVES, 2001; HARRINSON; WHITFIELD, 2012).

Trophic ecology studies seek to identify the feeding habits of species through the analysis of the major items consumed. Knowledge of the diets of species is one of the basic requirements for a closer examination of the relationships among organisms in a given ecosystem, as very close relationships exist between the quantity, quality, and availability of food and the distribution and abundance of consumer organisms. The structures of fish assemblages that use the shallow areas of estuaries are strongly influenced by trophic relationships. Knowledge of the trophic web allows one to describe energy flows in ecosystems and ecological relationships among organisms (PAIVA et al., 2008; DANTAS et al., 2013). Thus, it is important to understand the trophic relationships between fish and their potential prey to understand the relationships among fish in a community.

Marine Protected Areas (MPAs) are increasingly seen as important tools for the mangement of coastal ecosystems and fisheries, where significant effects at the fish assemblage level is marked in the total abundance, species richness and diversity of fishes in these areas (CLAUDET et al., 2006). Therefore, the present study aimed to characterise the trophic ecology of the major fish species caught on a tropical tidal mudflat to accomplish the following: (1) describe and examine the diets of species during different phases of the hydrological regime and (2) define the trophic guilds within the fish community of a tidal mudflat located in a tropical estuary with little anthropogenic influence.

\section{MATERIAL AND METHODS}

\section{STUDY AREA}

The Mamanguape River estuary is located on the north coast of the Paraíba state and extends for $25 \mathrm{~km}$ in an east-west direction and for $5 \mathrm{~km}$ in a north-south direction. It is part of the Environmental Protection Area (Área de Proteção Ambiental - APA) of Barra de Mamanguape (Figure 1). Its primary purpose is to protect marine biodiversity, to favor social and economic activities linked to the sea, especially fisheries, and to promote public education and scientific research. The regional climate is classified by Köppen as As-type (hot 
and humid). The rainy season begins in February and lasts until July, with maximum rainfall occurring from April to June, whereas the dry season occurs in the period from August to January, the lowest rainfall occurring between October and December (PEREIRA; ALVES, 2006). The average rainfall recorded in the area is between 1,750 and 2,000 $\mathrm{mm}$ annually, and the average temperature is approximately $24-26^{\circ} \mathrm{C}$. There is a well-preserved mangrove swamp in the area, composed of Avicennia germinans, Avicennia schaweriana, Conocarpus erectus, Laguncularia racemosa and Rhizophora mangle, which extends for 600 ha around the primary channel and tidal creek, in addition to Atlantic Forest remnants (ROCHA et al., 2008). Endangered species, such as the seahorse, Hippocampus reidi, and the West Indian manatee, Trichechus manatus, are also found in this estuary (MOURÃO; NORDI, 2003; CASTRO et al., 2008).

The Curva do Pontal beach (6 $6^{\circ} 46^{\prime} 27^{\prime \prime}$ S; 34 $55^{\prime} 20^{\prime \prime}$ $\mathrm{W})$, located $2.3 \mathrm{~km}$ upstream from the estuary mouth, is $1,200 \mathrm{~m}$ long and has very calm waters because of the diminished influence of waves (Figure 1). The beach is greatly influenced by the entrance of ocean waters, where marine sediments are regularly exposed and submerged by tidal action, and has a maximum depth of $4 \mathrm{~m}$. The tidal mudflat examined is a non-vegetated area with a gentle slope and fine muddy sediment in the intertidal zone; in the subtidal zone, seagrass, sessile invertebrates, macroalgae, mangrove leaves, and fallen branches form the benthic cover (XAVIER et al., 2012).

\section{SAMPLING PROGRAMME}

Samples were collected on monthly daytime excursions during spring low tides, in both the dry season (October 2010 to January 2011) and the rainy season (March to June 2011), to sample the ichthyofauna of the tidal mudflat more completely and efficiently during the local hydrological regime.

The fish were sampled using a beach seine $(10.0 \times 1.5 \mathrm{~m}$; $8 \mathrm{~mm}$ mesh size). The seine hauls were $30 \mathrm{~m}$ long, parallel and close to the shore, and were taken out to a depth of approximately $1.5 \mathrm{~m}$. The sampling unit was standardised with 5 replicates in an effort to capture individuals that use the area for feeding, $5 \mathrm{~m}$ apart to minimize the influence on the following haul. The collected fish were fixed in $10 \%$ formalin for later identification in the laboratory, according to FIGUEIREDO and MENEZES (1978, 1980, 2000), MENEZES and FIGUEIREDO (1980, 1985), and ARAÚJO et al. (2004). The total length (TL, mm) and body weight $(\mathrm{g})$ were measured for each individual. Temperature, salinity, and water transparency were measured, using a thermometer, an optical refractometer, and a Secchi disc, respectively.

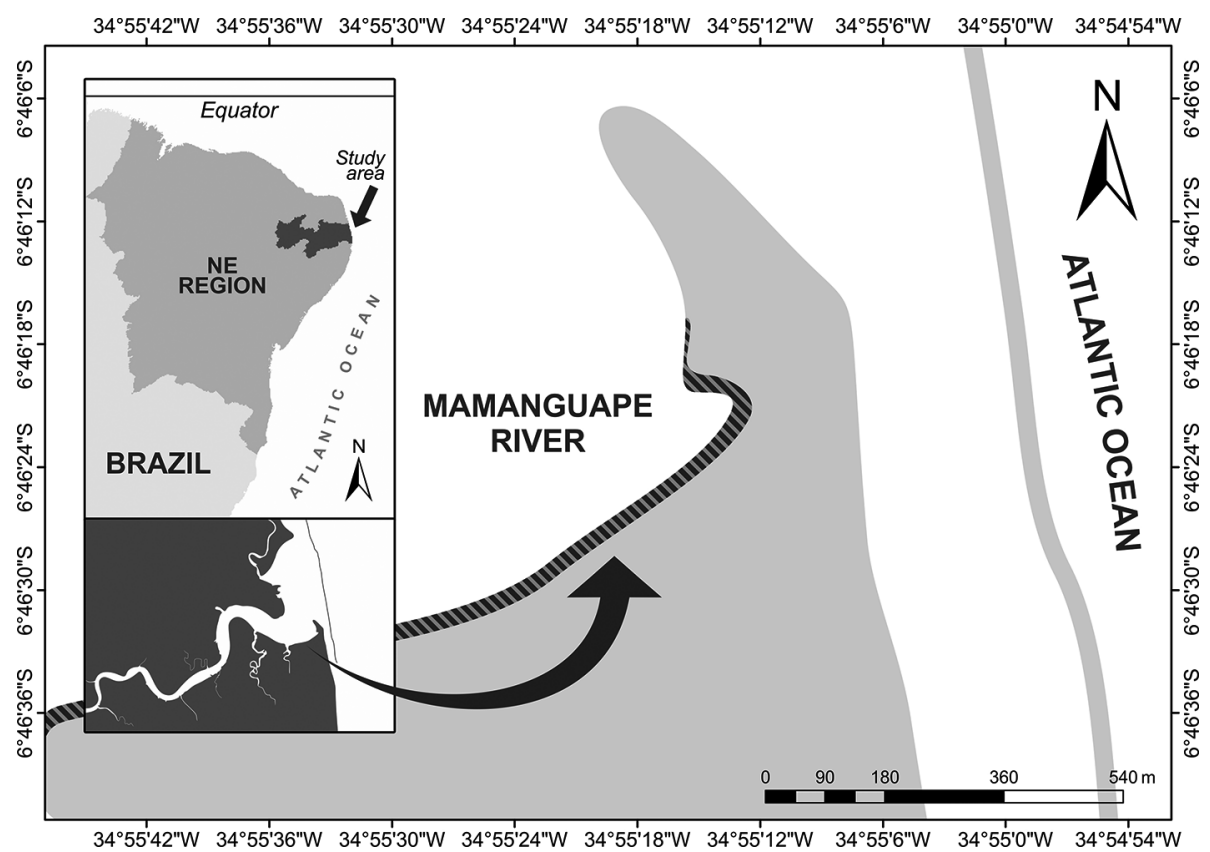

Figure 1. Map of the study area. The hatched area indicates the tidal mudflat studied in the Mamanguape River Estuary, Brazil. 


\section{DATA ANALYSIS}

Data from 17 predator species were included in the current analysis. We include numerically dominant, commercially valuable, and ecologically important species in the Mamanguape river estuary (XAVIER et al., 2012; OLIVEIRA; PESSANHA, 2014). To remove the stomach of each captured specimen, an incision was made in the abdominal region, from the anus toward the head. The stomachs were opened, and their contents arranged in a Petri dish for viewing. Content analysis was performed using a stereoscopic microscope, and food items were identified to the lowest possible taxonomic level and subsequently grouped into the following taxonomic categories: Plant Material (plant and algae debris); Zooplankton (Decapoda larvae, Calanoida and Cyclopoida copepods, invertebrates, and fish eggs); Insects; Polychaeta; Fish (scales and fish); Mollusca (Bivalvia, Gastropoda, and Scaphopoda); Decapoda (crabs and shrimp); Benthic or Epibenthic Crustaceans (Isopoda, Tanaidacea, Ostracoda, Caprella amphipods, Mysidacea, Gammaridea amphipods, Harpacticoida copepods, and Cirripedia); Infaune (Foraminifera, Sipuncula, Nematoda, and Trematoda); and Phytobenthos (diatoms).

To analyse each diet, the frequency of occurrence $(\% \mathrm{~F})$, the percentage number $(\% \mathrm{~N})$, and the volume $(\% \mathrm{~V})$ of different food items were calculated (HYSLOP, 1980), and the Index of Relative Importance (IRI) was subsequently applied (PINKAS et al., 1971). Although the IRI may not be a good index, as pointed out by MACDONALD and GREEN (1983), it was used in this paper because IRI has often been used in other studies on stomach contents and it facilitates comparison with the results of other studies (BARRY et al., 1996). For items that cannot be counted, a value of 0.1 was given for their number $(\% \mathrm{~N})$ when they were present in the diet, to offset distortions in the index (ABDURAHIMAN et al., 2010).

A non-hierarchical cluster analysis, based on the UPGAM (Unweighted Pair-Group Average) linkage method, was used to construct a dendrogram to identify guilds for each phase of the hydrological regime. These data were used to build a similarity matrix using the correlation coefficient. A cophenetic correlation analysis was employed to increase the reliability of conclusions drawn from the interpretation of the dendrogram. We adopted $\mathrm{rc}=0.80$ as the fidelity criterion for this analysis (ROMESBURG, 1984; KOPP et al., 2007). The trophic guilds were defined according to ELLIOTT et al. (2007).
Non-metric multidimensional scaling (nMDS) was applied to obtain a graphical representation of the trophic groups, using the volumetric measurement of food items. The Bray-Curtis coefficient was calculated for each fish species after a fourth-root transformation. For easy interpretation, the items were coded and grouped according to the taxonomic categories previously described. An ANOSIM (analysis of similarity) was used to test for differences in species between the phases of the hydrological regime and among the guilds. Prior to ordination (nMDS), the volumetric dietary data of each category for the diets of each individual of each fish species were treated in different ways according to the purpose of the analysis.

The trophic niche breadth (diet breadth) for each period of the hydrologic cycle was calculated using Levins' standardised index (KREBS,1989), which ranges from 0 , where a species consumed only 1 type of prey, to 1 , where a species similarly consumed various types of prey. To standardise the measure of each trophic niche we applied HURLBERT (1978). To calculate niche overlap, PIANKAS index (KREBS, 1989) was used, which measures the extent to which 2 species share a number of resources on a scale ranging from 0 to 1 . A score of 0 indicates that the 2 species are completely dissimilar, while a score of 1 indicates complete overlap.

To explain trophic relationships, dietary data were summarised into a trophic diagram. Links between fish and their prey were constructed by incorporating the contribution of the volume of different food items in the diet of each fish species during the different phases of the hydrological regime (rainy and dry). The volumetric dietary data is the better metric for quantifying the relative importance of different food items (HAMMERSCHLAG et al., 2010).

\section{RESULTS}

The temperature, salinity and transparency values were lowest in the rainy season and highest in the dry season, following a typical pattern for this tropical region (Figure 2). The temperature varied between $26^{\circ} \mathrm{C}$ and $34^{\circ} \mathrm{C}$ (dry season: $=29.6$, standard error $(\mathrm{SE})=0.49$; rainy season: $=29.5, \mathrm{SE}=0.32)$; salinity ranged between 10 and 42 (dry season: $=33.3, \mathrm{SE}=1.03$; rainy season: $=27.5$, $\mathrm{SE}=1.86)$; and transparency ranged between 10 and 80 $\mathrm{cm}$ (dry season: $=43.3, \mathrm{SE}=2.58$; rainy season: $=40.6$, $\mathrm{SE}=4.20)$. 


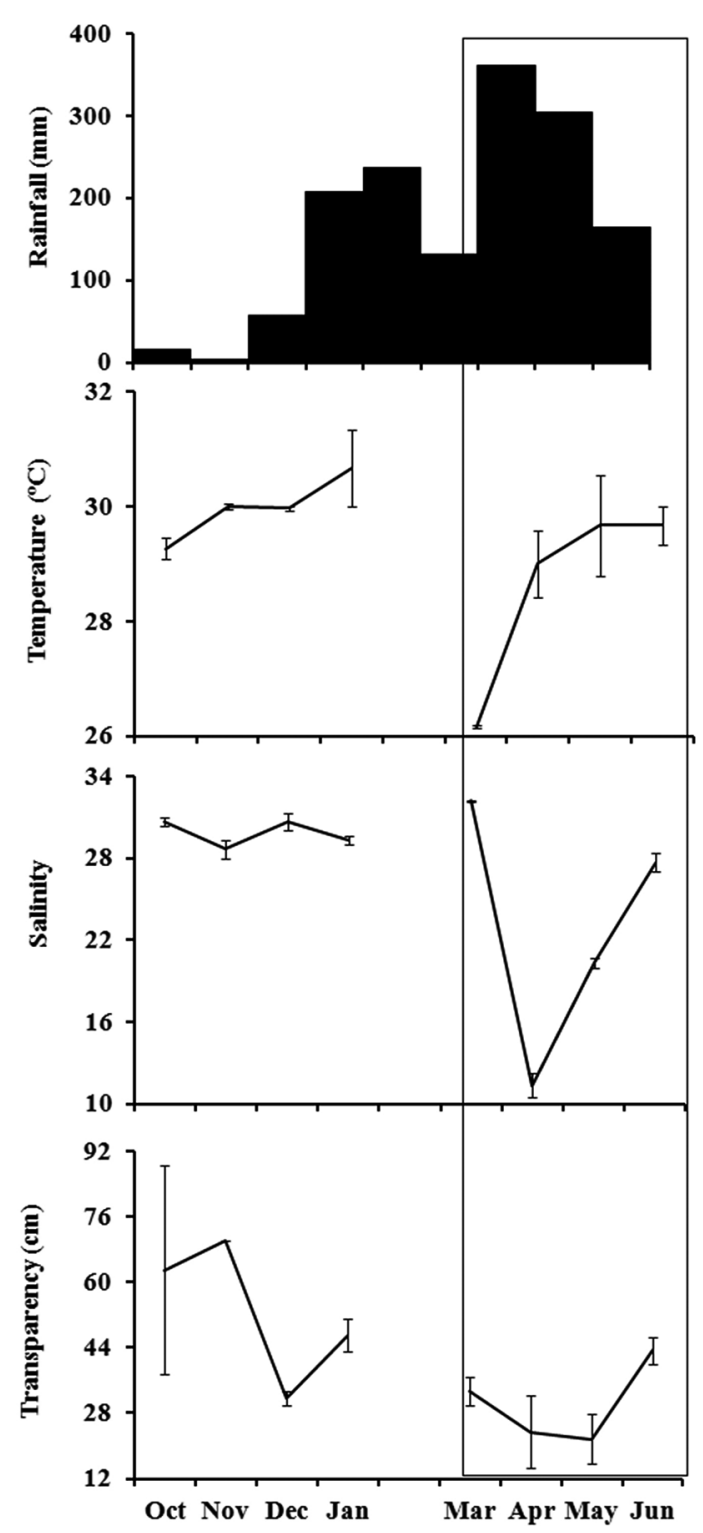

Figure 2. Monthly total rainfall and mean (standard error) temperature, salinity, and transparency in the Mamanguape River Estuary, Brazil. Demarcated area indicating rainy season.

The stomach contents of the total 1,867 individuals (representing more than $80 \%$ of the numerical abundance of fish on the tidal mudflat) caught during both periods of the hydrological regime were analysed (Table 1). The diets of the species studied were composed of 35 prey items, the Crustacea group being the most diverse, primarily because of zooplankton and small benthic crustaceans (Tables 2 and 3).

The Zooplanktivore guild was the most species-rich, while the Zoobenthivore-infaune and Insectivore were the most species-poor, with the latter guild present only during the rainy season. An analysis of the trophic guilds did not reveal any differences between the hydrological regime phases on the tidal flat studied (Figure 3 ). In the dry season, the cluster formed (cophenetic coefficient rc $=0.89$ ) comprised 5 different trophic guilds separated at the $40 \%$ similarity level: the first group consisted of 4 species of Zoobenthivore-epifaune feeding predominantly on Bivalvia and Gastropoda; the second group, containing 8 species, formed the Zooplanktivore guild; the third group, containing 2 species, formed the Piscivore guild; the fourth group consisted of only 1 species of the Zoobenthivore-infaune guild feeding predominantly on Polychaeta; and the fifth group consisted of 2 species that had diets based on organisms near the substrate (Detritivore), such as diatoms and foraminifera.

In the rainy season, 6 trophic guilds were formed via clustering (cophenetic coefficient $\mathrm{rc}=0.92$ ) separated at the $40 \%$ similarity level: the first and second groups were each composed of only 1 species that fed on Insects and Polychaeta (Zoobenthivore-infaune), respectively; the third group consisted of 2 species of Mollusca eaters (Zoobenthivore-epifaune); the fourth group was formed by 6 species consuming zooplanktivorous organisms; the fifth group consisted of 4 species of fish consumers; and the sixth group was formed by 2 species that were consumers of organisms near the substrate, such as Infaune and Phytobenthos (diatoms) (Figure 4).

The dendrogram analysis revealed that most species remained within the same trophic guilds during both phases of the hydrological regime (Figure 3 and 4). However, 5 species changed guilds: during the dry season, $A$. brasiliensis and $H$. unifasciatus were categorised as Zoobenthivoreepifaune, but, in the rainy season, they moved to the Zooplanktivore and Insect eater guilds, respectively; $B$. soporator, which was part of the Zooplanktivore guild in the dry season, was categorised as a Zoobenthivoreepifaune in the rainy season; and C. macrops and O. saurus were in the Zooplanktivore guild during the dry season but were categorised as Piscivore during the rainy season.

The nMDS showed no distinction between hydrological periods, a result corroborated by the ANOSIM value (global $\mathrm{R}=0.067, p=0.122$ ) (Figure 5). However, when the samples were coded by trophic guild, a very clear separation was evident (global $\mathrm{R}=0.404, p=0.001$ ): the Detritivore group were plotted in middle right, Piscivore and Zoobenthivore-infaune in the extreme lower left, Zoobenthivore-epifaune through middle left to upper centre, while the dominant group, the Zooplanktivore guild, was distributed throughout the diagram (Figure 5). 
Table 1. Number of individuals captured on the tidal mudflat during the dry and rainy seasons in a tropical estuary in Brazil.

\begin{tabular}{|c|c|c|c|c|c|c|c|c|c|c|c|}
\hline \multirow[b]{2}{*}{ Families } & \multirow[b]{2}{*}{ Species } & \multicolumn{5}{|c|}{ Dry season } & \multicolumn{5}{|c|}{ Rainy season } \\
\hline & & $\mathbf{N}$ & B & $\mathbf{F}$ & $\begin{array}{c}\text { TL } \\
(\text { mean } \pm \text { SD })\end{array}$ & $\begin{array}{c}\text { TL } \\
\text { (range) }\end{array}$ & $\mathbf{N}$ & B & $\mathbf{F}$ & $\begin{array}{c}\text { TL } \\
(\text { mean } \pm \text { SD })\end{array}$ & $\begin{array}{c}\text { TL } \\
\text { (range) }\end{array}$ \\
\hline \multirow{2}{*}{ Engraulidae } & Anchovia clupeoides & 47 & 89.8 & 14.8 & $106 \pm 6.7$ & $95-134$ & 20 & 84.6 & 12.0 & $81 \pm 3.6$ & $75-87$ \\
\hline & Lycengraulis grossidens & 57 & 1704.1 & 40.0 & $58 \pm 22.2$ & $20-214$ & 328 & 174.9 & 24.0 & $42 \pm 12.3$ & $25-143$ \\
\hline \multirow{2}{*}{ Clupeidae } & Harengula clupeola & 08 & 78.1 & 14.2 & $75 \pm 11.1$ & $65-95$ & 08 & 35.4 & 10.3 & $65 \pm 5.3$ & $60-76$ \\
\hline & Rhinosardinia bahiensis & 155 & 8143.2 & 37.1 & $74 \pm 8.0$ & $60-106$ & 119 & 350.0 & 16.0 & $73 \pm 6.4$ & $54-88$ \\
\hline Hemiramphidae & Hyphorhamphus unifasciatus & 70 & 120.1 & 37.2 & $137 \pm 38.7$ & $60-183$ & 26 & 198.1 & 36.0 & $154 \pm 28.5$ & $81-202$ \\
\hline Atherinopsidae & Atherinella brasiliensis & 191 & 412.7 & 45.7 & $95 \pm 19.9$ & $27-130$ & 258 & 414.8 & 60.0 & $42 \pm 32.4$ & $17-120$ \\
\hline Mugilidae & Mugil liza & 45 & 43.4 & 20.0 & $29 \pm 4.7$ & $20-58$ & 208 & 27.1 & 44.0 & $31 \pm 4.1$ & $17-52$ \\
\hline \multirow{2}{*}{ Gerreidae } & Eucinostomus argenteus & 20 & 79.0 & 28.5 & $63 \pm 22.7$ & $16-105$ & 27 & 52.4 & 20.0 & $18 \pm 13.7$ & $10-100$ \\
\hline & Eucinostomus melanopterus & 3 & 0.64 & 2.9 & $54 \pm 11.9$ & $47-68$ & 31 & 7.0 & 24.0 & $23 \pm 12.7$ & $15-50$ \\
\hline \multirow{2}{*}{ Carangidae } & Caranx latus & 18 & 41.2 & 28.6 & $61 \pm 14.5$ & $42-104$ & 29 & 148.6 & 28.0 & $68 \pm 11.5$ & $26-95$ \\
\hline & Oligoplites saurus & 08 & 5.2 & 5.7 & $63 \pm 25.0$ & $31-103$ & 06 & 6.5 & 20.0 & $62 \pm 9.1$ & $52-76$ \\
\hline Gobiidae & Bathigobius soporator & 08 & 49.5 & 20.0 & $88 \pm 15.8$ & $70-122$ & 04 & 45.9 & 20.0 & $74 \pm 21.6$ & $37-104$ \\
\hline \multirow{3}{*}{ Paralichthyidae } & Citharichthys spilopterus & 16 & 43.7 & 8.6 & $82 \pm 11.2$ & $67-101$ & 07 & 37.9 & 20.0 & $93 \pm 37.1$ & $14-143$ \\
\hline & Citharichthys macrops & 33 & 50.9 & 20.0 & $72 \pm 28.8$ & $22-140$ & 08 & 26.3 & 24.0 & $53 \pm 20.9$ & $18-130$ \\
\hline & Achirus lineatus & 19 & 54.3 & 31.4 & $56 \pm 46.1$ & $15-114$ & 03 & 43.6 & 8.0 & $45 \pm 10.8$ & $15-62$ \\
\hline \multirow{2}{*}{ Tetraodontidae } & Sphoeroides testudineus & 51 & 698.9 & 45.7 & $125 \pm 48.9$ & $21-197$ & 27 & 1083.7 & 48.0 & $104 \pm 54.5$ & $12-236$ \\
\hline & Sphoeroides greeley & 03 & 62.7 & 14.3 & $68 \pm 17.3$ & $39-81$ & 06 & 75.4 & 20.0 & $52 \pm 18.7$ & $23-74$ \\
\hline
\end{tabular}

N: number of individuals; B: Biomass (in grams); F: frequency of occurrence; TL: total length, in mm. (mean \pm SD - standard deviation).

Overall, the niche breadth values were higher during the rainy season. The species A. lineatus, E. argenteus, and $A$. clupeoides had the highest niche breadth values during the rainy season, and O. saurus, L. grossidens, and $S$. greeleyi had the highest values in the dry season. The flatfish C. spilopterus showed the lowest values during the dry season whereas $O$. saurus during the rainy season (Figure 6). Interspecific overlap values varied according to the period analysed, with only one comparison $(\mathrm{Rb} \times \mathrm{Hc})$ remaining significant during both phases of the hydrological regime; the largest number of overlaps was observed among individuals within the same trophic guilds, primarily in the Zooplanktivore and Zoobenthivore-epifaune guilds (Table 4).

The trophic organisations differed during different phases of the hydrological regime, with a larger number of trophic links being observed during the rainy season when compared to the dry season (Figure 7). A pattern was also observed in the values of trophic links, with higher values occurring during the dry season when compared to the rainy season. During both phases of the hydrological regime, a larger number of links with low values was indicative of trophic resource partitioning

\section{DISCUSSION}

The trophic guilds described for the tidal mudflat of the Mamanguape River estuary did not vary between hydrological regime periods; for both periods, the Zooplanktivore was the most species-rich, indicating the high abundance of zooplankton in the study area. In general, the results of the present study were similar to those of other studies of estuarine environments, corroborating the hypothesis that, although fish species composition may differ considerably among estuaries, the basic trophic structure within an estuary is usually very similar (ELLIOTT; DEWAILLY, 1995; BARLETTA; BLABER, 2007). Studies of South African estuarine ichthyofauna (HARRINSON; WHITFIELD, 2012) indicate that Zooplanktivore species were a dominant component in subtropical estuaries, probably due to river flow and nutrient supply within this region, whereas another study at that tropical bay also found Calanoida as the primary food resource for dominant fishes species (HAJISAME; IBRAHIM, 2008). Comparative studies indicate that, in environments devoid of vegetation (nonvegetated), carnivorous and omnivorous species consume 
Campos et al.: Trophic relationships of fish assemblages

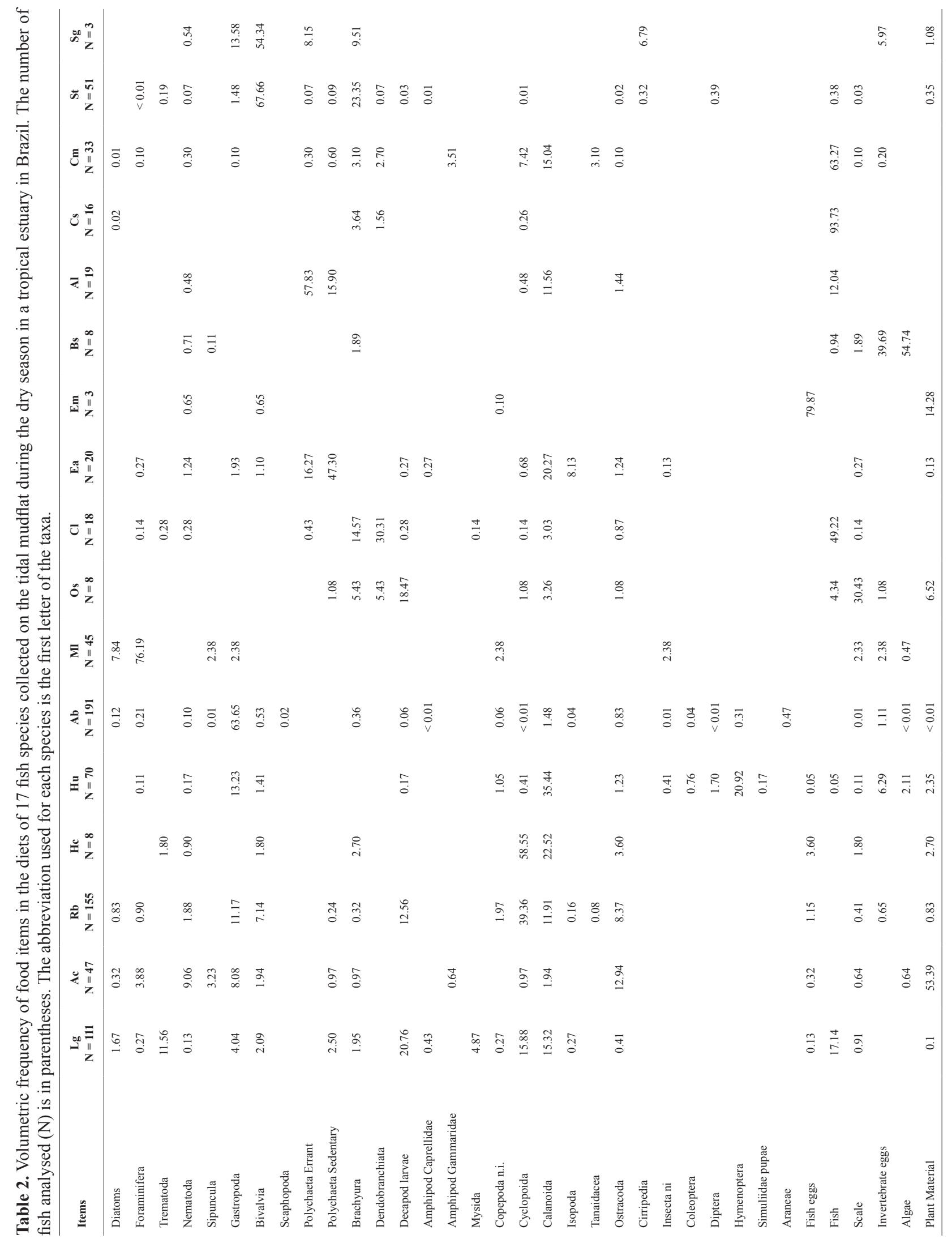




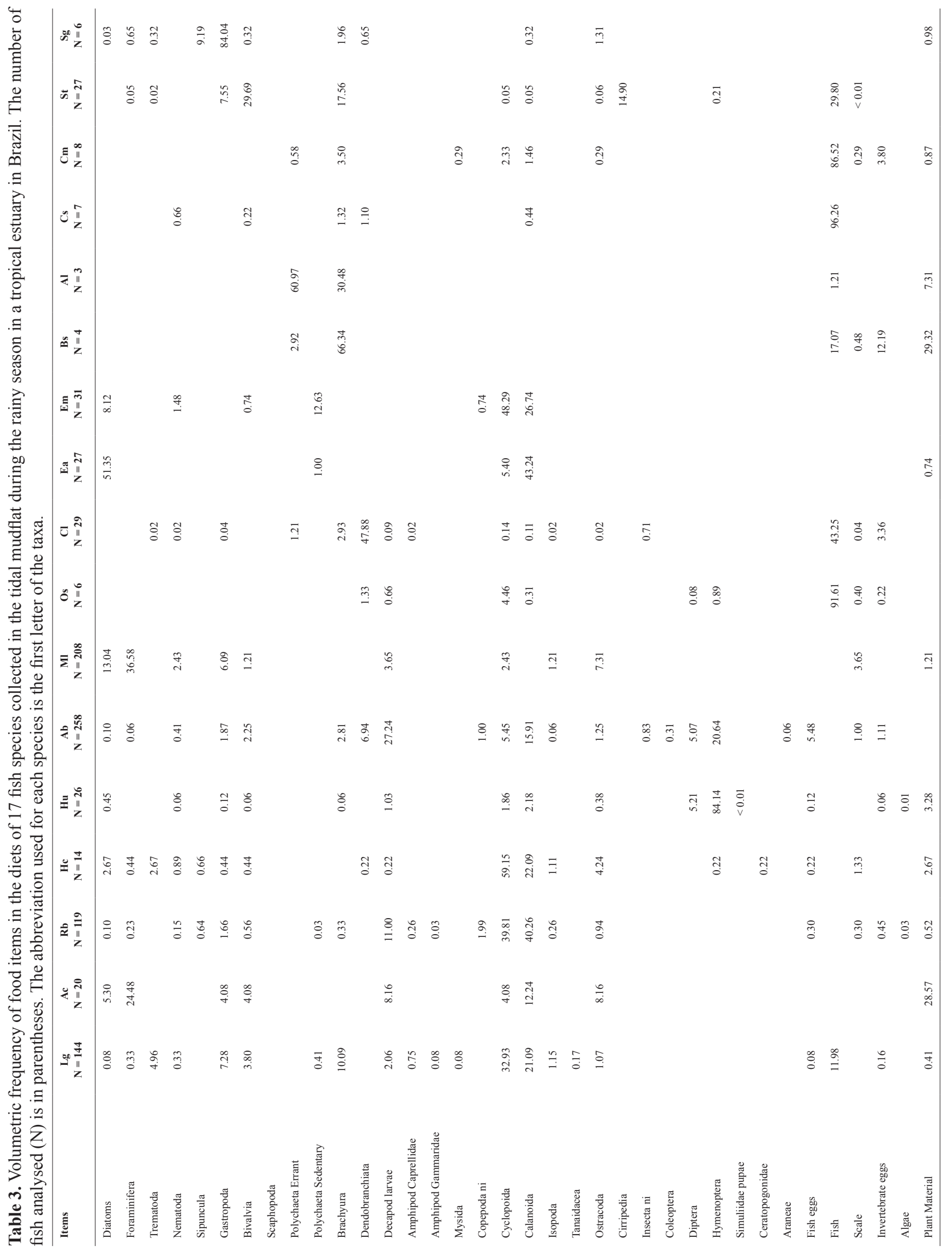




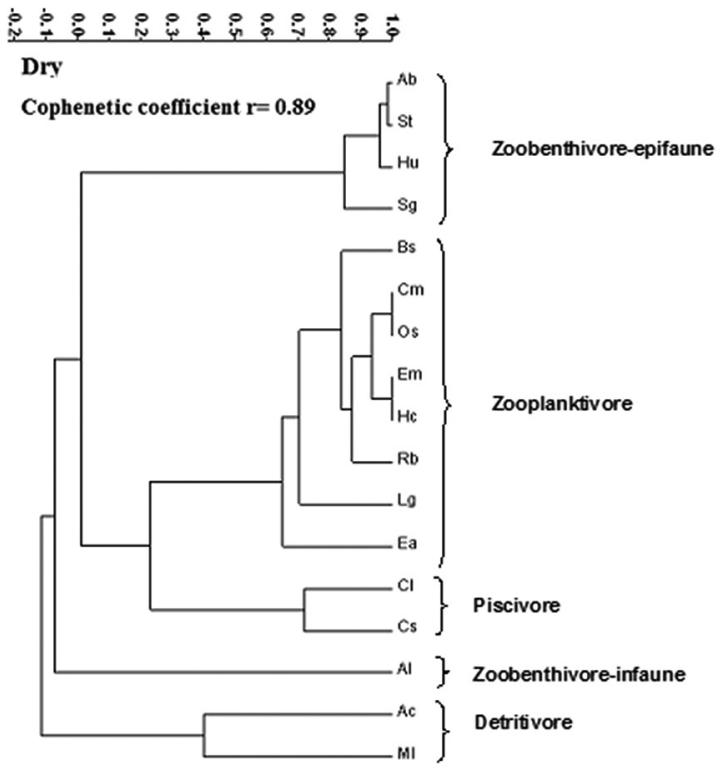

Figure 3. Dendrogram of the guild structure of the fish assemblage on the tropical tidal mud flat during the dry period, determined using correlation similarities of the Index of Relative Importance. The abbreviation used for each species is the first letter of the taxa.

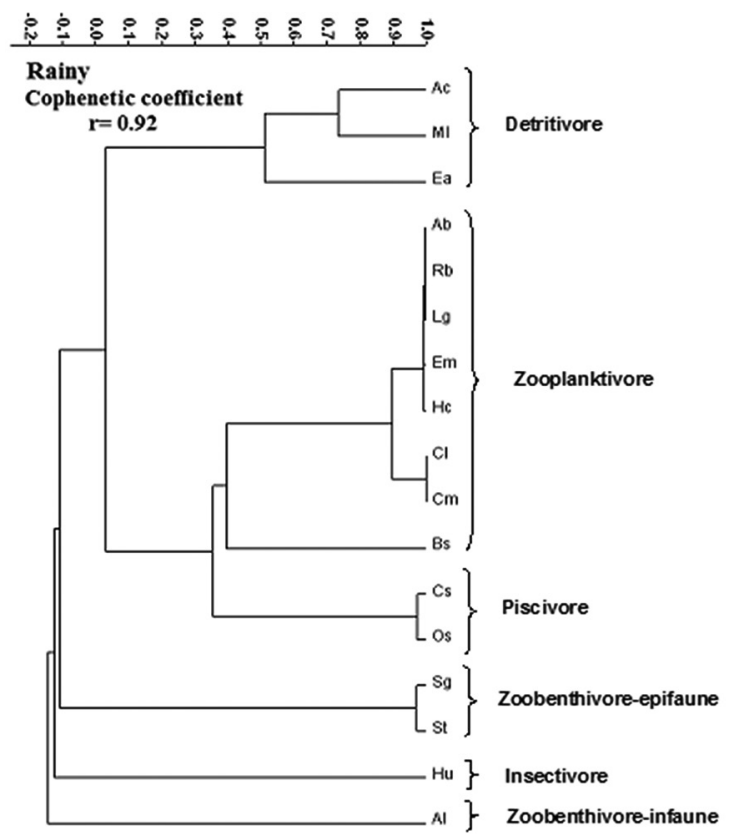

Figure 4. Dendrogram of the guild structure of the fish assemblage on the tropical tidal mud flat during the rainy season, determined using correlation similarities of the Index of Relative Importance. The abbreviation used for each species is the first letter of the taxa.

pelagic prey present in the water column (ANGEL; OJEDA, 2001). In addition, tidal mudflats are recognised as areas that are protected from wind and wave action,
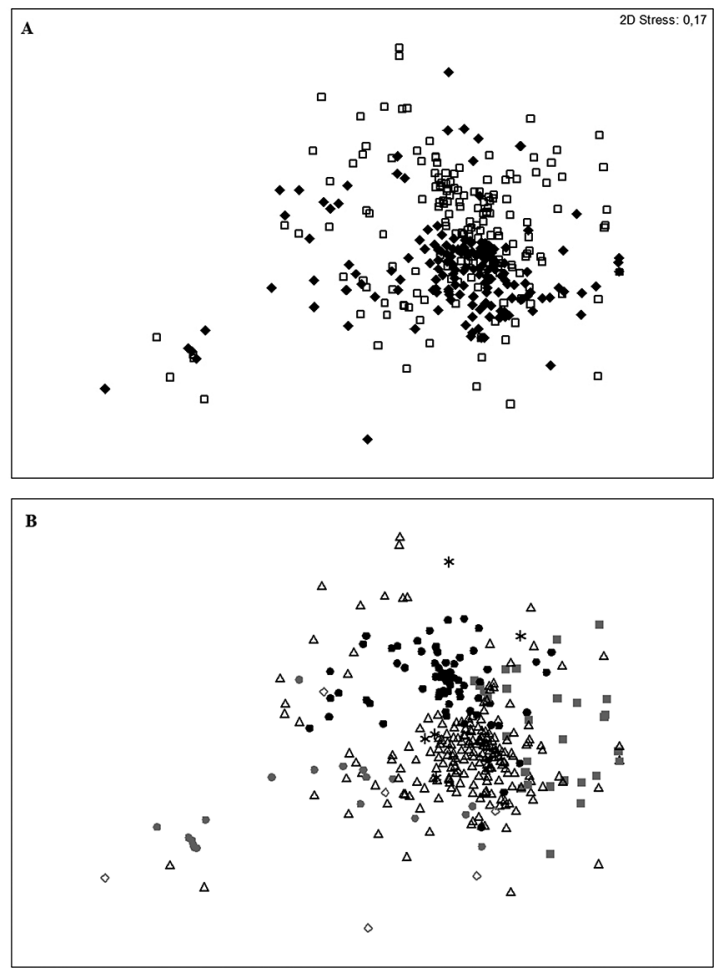

Figure 5. Nonmetric multidimensional scaling (nMDS) ordination of the dietary similarities for 17 species collected on the tropical tidal mud flat: (A) during the dry (black diamond) and rainy (square) seasons; (B) Trophic guilds are: Gray square: Detritivore; triangle: Zooplanktivore; gray circle: Piscivore; black circle: Zoobenthivore-epifaune; asterisk: Insectivore; diamond: Zoobenthivore-infaune.

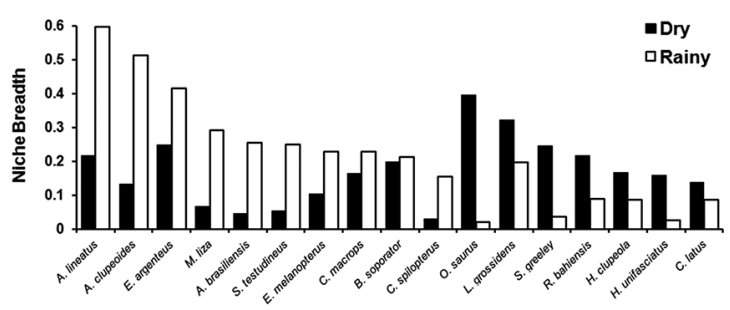

Figure 6. Dietary breadths of the 17 species collected in the tropical tidal mud flat during the dry and rainy seasons.

having calm waters that retain holo- and meroplankton (ARCHAMBAULT et al., 1998), which, in the present study, stood out as consumed prey.

Although the number of guilds was constant, their compositions changed, as observed in the Zooplanktivore and Zoobenthivore-epifaune guilds. The increase, decrease, or replacement of species within a guild is a result to be expected in tropical regions (BARLETTA; BLABER, 2007). For example, BALDÓ and DRAKE (2002) suggested that the mysids (hyperbenthic) replace copepods (zooplanktonic) progressively in the diet of juvenile fish 
Table 4. Pianka overlap index between the diets of 17 species collected in the tropical tidal mud flat during the dry (lower half of the matrix) and rainy period (upper half of the matrix). Values $>0.6$ are in bold. The abbreviation used for each species is the first letter of the taxa.

\begin{tabular}{|c|c|c|c|c|c|c|c|c|c|c|c|c|c|c|c|c|c|}
\hline Dry/Rainy & Al & Ac & Ab & Bs & Cl & Cs & $\mathrm{Cm}$ & Ea & Em & Hc & Hu & MI & Os & $\mathbf{R b}$ & Sg & St & Lg \\
\hline Al & - & 0.02 & 0.00 & 0.48 & 0.29 & 0.37 & 0.14 & 0.00 & 0.09 & 0.00 & 0.01 & 0.01 & 0.40 & 0.00 & 0.00 & 0.39 & 0.16 \\
\hline Ac & 0.00 & - & 0.28 & 0.09 & 0.00 & 0.00 & 0.02 & 0.29 & 0.24 & 0.24 & 0.04 & 0.62 & 0.00 & 0.31 & 0.11 & 0.07 & 0.19 \\
\hline $\mathbf{A b}$ & 0.00 & 0.13 & - & 0.02 & 0.00 & 0.00 & 0.02 & 0.27 & 0.30 & 0.27 & 0.54 & 0.08 & 0.02 & 0.50 & 0.05 & 0.05 & 0.27 \\
\hline Bs & 0.00 & 0.01 & 0.31 & - & 0.21 & 0.23 & 0.14 & 0.00 & 0.05 & 0.00 & 0.00 & 0.00 & 0.24 & 0.00 & 0.00 & 0.49 & 0.26 \\
\hline Cl & 0.43 & 0.01 & 0.00 & 0.01 & - & 0.61 & 0.19 & 0.01 & 0.15 & 0.00 & 0.00 & 0.00 & 0.66 & 0.00 & 0.00 & 0.42 & 0.12 \\
\hline Cs & 0.53 & 0.00 & 0.00 & 0.00 & 0.01 & - & 0.24 & 0.00 & 0.20 & 0.00 & 0.00 & 0.00 & 0.89 & 0.00 & 0.00 & 0.55 & 0.15 \\
\hline $\mathrm{Cm}$ & 0.25 & 0.01 & 0.00 & 0.01 & 0.76 & 0.37 & - & 0.02 & 0.11 & 0.05 & 0.00 & 0.00 & 0.27 & 0.05 & 0.00 & 0.19 & 0.15 \\
\hline $\mathbf{E a}$ & 0.02 & 0.04 & 0.05 & 0.00 & 0.02 & 0.00 & 0.13 & - & 0.46 & 0.33 & 0.02 & 0.23 & 0.00 & 0.50 & 0.00 & 0.00 & 0.32 \\
\hline Em & 0.02 & 0.17 & 0.00 & 0.00 & 0.00 & 0.00 & 0.00 & 0.00 & - & 0.95 & 0.03 & 0.08 & 0.26 & 0.91 & 0.00 & 0.14 & 0.27 \\
\hline Hc & 0.04 & 0.08 & 0.01 & 0.00 & 0.03 & 0.00 & 0.24 & 0.17 & 0.06 & - & 0.03 & 0.08 & 0.04 & 0.88 & 0.01 & 0.00 & 0.18 \\
\hline Hu & 0.03 & 0.12 & 0.29 & 0.00 & 0.04 & 0.00 & 0.23 & 0.36 & 0.01 & 0.29 & - & 0.08 & 0.01 & 0.03 & 0.00 & 0.00 & 0.01 \\
\hline MI & 0.00 & 0.07 & 0.03 & 0.00 & 0.00 & 0.00 & 0.00 & 0.00 & 0.00 & 0.00 & 0.01 & - & 0.00 & 0.06 & 0.15 & 0.04 & 0.11 \\
\hline Os & 0.00 & 0.16 & 0.02 & 0.00 & 0.12 & 0.00 & 0.12 & 0.04 & 0.02 & 0.06 & 0.07 & 0.02 & - & 0.03 & 0.00 & 0.61 & 0.16 \\
\hline $\mathbf{R b}$ & 0.04 & 0.11 & 0.24 & 0.00 & 0.02 & 0.00 & 0.20 & 0.15 & 0.02 & 0.90 & 0.29 & 0.03 & 0.17 & - & 0.03 & 0.01 & 0.36 \\
\hline Sg & 0.00 & 0.08 & 0.22 & 0.00 & 0.00 & 0.00 & 0.00 & 0.08 & 0.10 & 0.03 & 0.09 & 0.00 & 0.00 & 0.20 & - & 0.15 & 0.17 \\
\hline $\mathbf{S t}$ & 0.00 & 0.04 & 0.02 & 0.00 & 0.05 & 0.00 & 0.01 & 0.02 & 0.00 & 0.03 & 0.03 & 0.00 & 0.02 & 0.15 & 0.93 & - & 0.26 \\
\hline Lg & 0.03 & 0.56 & 0.11 & 0.00 & 0.41 & 0.00 & 0.57 & 0.22 & 0.10 & 0.56 & 0.38 & 0.01 & 0.20 & 0.51 & 0.08 & 0.07 & - \\
\hline
\end{tabular}

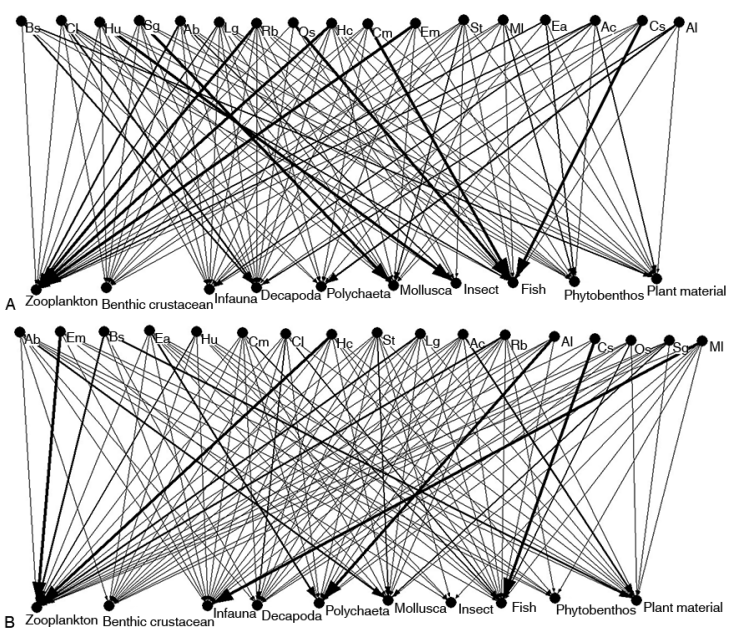

Figure 7. Trophic model of the fishes collected from the tidal mudflat (Brazil) and their prey in the (A) dry and (B) rainy seasons. The fishes (top) are arranged from left to right in order of increasing population based on the dietary niche breadth. The widths of the linking lines correspond to the contributions by volume of different food items in the fish diets.

species as they grow in the tropical estuary. DEGRÉ et al. (2006) found that the grazing fish, which kept a roughly balanced diet between microphytobenthos and detritus, changed their exclusively herbivorous diet during summer to prey on nematofauna during winter on a mudflat. This fluidity among guilds exists because ecological interactions among species are intensified at certain periods, with the less competitive species or species more susceptible to predation being excluded or replaced by species with greater adaptability to environmental pressures (ARAÚJO et al., 2006). Although ontogenetic changes were not specifically examined in the present study, some authors have asserted that certain species may segregate into different guilds during growth (LEGUERRIERA et al., 2007; ABDURAHIMAN et al., 2010).

Autochthonous prey items, represented primarily by zooplankton and, in particular, by copepods, are of fundamental importance for juveniles. The dominance and wide range of small organisms, which confer immediate availability and ease of capture by fish, are striking features in estuarine areas (INOUE et al., 2005; KELLNREITNER et al., 2012). The wide availability of these prey items is a good indicator of the value of tidal mudflats as nursery grounds for biotopes, as fish choose habitats that provide high abundance and diversity of prey. Prey density is important in determining the survival of fish larvae and juveniles, and growth may be affected when prey density becomes critical (BUSKEY et al., 1993). In estuarine ecosystems, zooplankton are considered to be the basis of the pelagic chain, connecting the input of matter transported by rivers and macrofauna (LOBRY et al., 2008), in addition to being used by pelagic 
species of the families Engraulidae (A. clupeoides and $L$. grossidens) and Clupeidae (R. bahiensis and H. clupeola), which were highly abundant in this tropical estuary. The clupeiformes were important consumers of this prey in the Guadalquivir Estuary (BALDÓ; DRAKE, 2002) and in habitats of the lower reaches of the Caeté Estuary (BARLETTA; BLABER, 2007).

The stability of biological communities partially depends on the availability of food items and on the stability of the trophic interactions among species. Changes in the proportion of available allochthonous and autochthonous resources and in the primary productivity of an estuarine system are common when comparing dry and rainy seasons, and the presence of some trophic guilds in one season but not the other may be the result of changes in prey availability (LOBRY et al., 2008). The input of allochthonous material during the rainy season and its importance to the tidal mudflat is evidenced by the formation of the Insectivorous guild (represented by $H$. unifasciatus). The uniform presence of some species in the same guild, such as A. lineatus, C. spilopterus, and $S$. testudineus and $S$. greeleyi, during the periods studied was also observed, indicating that the environmental stability of tidal mudflats may have contributed to this result.

A large number of possible interconnections among prey and predators reflects the degree of opportunism, which is likely to be a key factor in promoting the survival of the species (DOLBETH et al. 2008), in addition to generalism, which tends to reduce overlap among estuarine fishes (GARRISON; LINK, 2000). Diet analysis showed changes in key prey types between hydrological periods, indicating an opportunistic trophic strategy for the species studied. The Brazilian silverside, A. brasiliensis, consumed Gastropoda, Bivalvia, and algae, linked to the benthonic domain, during the dry season, while, in the rainy season, the species consumed items linked to zooplankton, such as copepods and Decapoda larvae; $H$. unisfasciatus consumed primarily algae, Gastropoda, and Hymenoptera in the dry season, while, in the rainy season, only Hymenoptera had a significant value in the diet of this species; and, for the Clupeiformes, L. grossidens, A. clupeoides, and $R$. bahiensis, the diet during the dry season consisted mostly of zooplankton or epibenthic organisms, while, in the rainy season, their diet was based primarily on zooplankton. In other shallow ecosystems along the Brazilian coast, both in subtropical and tropical areas, the reported dietary items have been very similar to those found in the present study (BORTOLUZZI et al., 2006;
ROCHA et al., 2008; VASCONCELOS-FILHO et al., 2009; CONTENTE et al., 2011).

When several teleosts are found in the same environment and are characterised by having wide a range of ecological niches and high trophic flexibility, the potential for interspecific competition is reduced through resource partitioning (ROSS, 1986). In the estuary studied, teleosts took advantage of temporal variations that affect the density of prey and/or the abundance of resources. Trophic flexibility leads to high diet overlap among species, as there is no need to partition the available resources, especially among species of the same guild, as was observed in some comparisons between the Zooplanktivore and Zoobenthivore-epifaune. Despite significant overlap values, there was no indication of competition for resources because, when resources are abundant, competition is absent (SCHONER, 1982), and temporal segregation is a strategy that minimises direct confrontation in the use of resources. When resource partitioning becomes important in the organisation of fish assemblages, species segregate along the resource dimension and demonstrate decreased niche breadth to maintain the minimum level of niche separation (LABROPOULOU; ELEFTHERIOU, 1997).

Niche breadth was higher during one season of the hydrological regime than the other, depending on the species group analysed. Some Zooplanktivores and Piscivores had lower niche breadth values during the rainy season. During the rainy season, system productivity is greater because of increased organic matter input, resulting in greater prey abundance. Increased prey abundance should result in lower niche breadth values (WOOTON, 1990), as was observed for H. clupeola, S. greeleyi, $R$. bahiensis, and O. saurus. During the dry season, predators become less selective and niche breadth increases, as was observed for M. liza, E. argenteus and A. clupeoides. Resident estuarine species, such as A. brasiliensis, $S$. testudineus, A. linetaus, and C. spilopterus, had higher niche breadth values in the rainy season, when dominant prey were abundant, but tended to specialise in the dry season, when organisms were less abundant. TSE et al. (2008) suggested that the foraging efficiency of juvenile fishes might be responsible for differences in diet breadth among juvenile fishes in a mudflat habitat.

Tropical environments have great fish diversity, a phenomenon that can be explained by the existence of trophic resource partitioning, which allows for the coexistence of species in shallow coastal ecosystems. 
By analysing trophic links in the dry and rainy seasons, a wide variety of items consumed by all species was observed, indicating high complexity and connectivity, as well as partitioning of the same food item by several species. Trophic web models are frequently used to describe relationships among individuals in estuaries because they summarise the vast complexity of the data (LUCZKOVICH et al., 2002). In the present study, most of the arrows in the trophic webs represented low percentage volume values, indicating the low consumption of certain food items, which allows more individuals to consume the items; that is, there was a greater partitioning of the resources available on this tidal mudflat. The large number of possible interconnections among prey and predators reflects the degree of opportunism, which is most likely a key aspect that enables success in estuarine environments (DOLBETH et al., 2008).

\section{ACKNOWLEDGEMENTS}

We thank biologists Nathalia Italiano Medeiros, Gabriela Guerra Araújo Abrantes, Bianca Bezerra Fialho Soares and Renato Pereira Dantas for helping in the field work and SISBIO for the permission to carry out the research in the protected area (24557). This study was partially supported by the National System of Research on Biodiversity (SISBIOTA/BRASIL) and CNPq - Brazilian National Agency for Scientific and Technological Development (Proc. 563202/2010-6 and Proc. 477663/2011-7).

\section{REFERENCES}

ABDURAHIMAN, K. P.; NAYAK, T. H.; ZACHARIA, P.U.; MOHAMED, K. S. Trophic organisation and predatorprey interactions among commercially exploited demersal finfishes in the coastal Waters of the southeastern Arabian sea. Estuar. Coast. Shelf Sci., v. 87, n. 4, p. 601-610, 2010.

ANGEL, A.; OJEDA, F. P. Structure and trophic organization of subtidal fish assemblages on the northern Chilean coast: the effect of habitat complexity. Mar. Ecol. Prog. Ser., v. 217, p. 81-91, 2001.

ARAÚJO, F. G.; GUIMARÃES, F. J. C.; COSTA, R. C. Environmental influences on distribution of four Sciaenidae species (Actinopterygii, Perciformes) in a tropical bay at Southeastern Brazil. Rev. Bras. Zool., v. 23, n. 2, p. 497-508, 2006.

ARAÚJO, M. E.; TEIXEIRA, J. M. C.; OLIVEIRA, A. M. E. Peixes estuarinos do nordeste brasileiro: Guia Ilustrado. Recife: Universitária UFPE e EFC, 2004. 260 p.

ARCHAMBAULT, P.; ROFF, J. C.; BOURGET, E.; BANG, B.; INGRAM, G. R. Nearshore abundance of zooplankton in relation to shoreline configuration and mechanisms involved. J. Plankton Res., v. 20, n. 4, p. 671-690, 1998.
BALDÓ, F.; DRAKE, P. A multivariate approach to the feeding habits of small fishes in the Guadalquivir Estuary. J. Fish Biol., v. 61, p. 21-32, 2002.

BARLLETA, M.; BLABER, S. J. M. Comparison of fish assemblages and guilds in tropical habitats of the Embley (Indo-West Pacific) and Caeté (Western Atlantic) estuaries. Bull. Mar. Sci., v. 80, n. 3, p. 647-680, 2007.

BARRY, J. M.; YOKLAVICH, M. M.; CAILLIET, G. M.; AMBROSE, D. A.; ANTRIM, B. S. Trophic ecology of dominant fishes in Elkhorn Slough, California, 1974-1980. Estuaries, v. 19, n. 1, p. 115-138, 1996.

BOER, W. F.; PRINS, H. H. T. The community structure of a tropical intertidal mudflat under human exploitation. ICES J. Mar. Sci., v. 59, n. 6, p. 1237-1247, 2002.

BORTOLUZZI, T.; ASCHENBRENNER, A. C.; SILVEIRA, C. R.; ROOS, D. C.; LEPKOSKI, E. D.; MARTINS, J. A.; GOULART, M. G.; QUEROL, E.; QUEROL, M. V. Hábito alimentar da Sardinha Prata, Lycengraulis grossidens (Spix \& Agassiz, 1829), (Pisces, Engraulidae), Rio Uruguai Médio, Sudoeste do Rio Grande do Sul, Brasil. Biodivers. Pampeana, v. 4, p. 11-23, 2006.

BUSKEY, E. J.; COUTER, C.; STROM, S. Locomotory patterns of microzooplankton: potential effects on food selectivity of larval fish. Bull. Mar. Sci., v. 53, n. 1, p. 29-43, 1993.

CASTRO, A. L. C.; DINIZ, A. F.; MARTINS, I. Z.; VENDEL, A. L.; OLIVEIRA, T. P. R.; ROSA, I. M. L. Assessing diet composition of seahorses in the wild using a non-destructive method: Hippocampus reidi (Teleostei: Syngnathidae) as a study-case. Neotrop. Ichthyol., v. 6, n. 4, p. 637-644, 2008.

CLAUDET, J.; PELLETIER, D.; JOUVENELC, J. Y.; BACHETD, F.; GALZIN, R. Assessing the effects of marine protected area (MPA) on a reef fish assemblage in a northwestern Mediterranean marine reserve: identifying community-based indicators. Biol. Conserv., v. 130, n. 6, p. 349-369, 2006.

CONTENTE, R. F.; STEFANONI, M. F.; SPACH, H. L. Feeding ecology of the Brazilian silverside Atherinellabrasiliensis (Atherinopsidae) in a sub-tropical estuarine ecosystem. J. Mar. Biol. Assoc. U. K., v. 91, n. 6, p. 1197-1205, 2011.

DANTAS, D. V.; BARLETTA, M.; RAMOS, J. A. A.; LIMA, A. R. A.; COSTA, M. F. Seasonal diet shifts and overlap between two sympatric catfishes in an estuarine nursery. Estuaries, v. 36, n. 2, p. 237-256, 2013.

DEGRÉ, D.; LEGUERRIER, D.; DU CHATELET, E. A.; RZEZNIK, J.; AUGUET, J.; DUPUY, C.; MARQUIS, E.; FICHET, D.; STRUSKI, C.; JOYEUX, E.; SAURIAU, P.; NIQUIL, N. Comparative analysis of the food webs of two intertidal mudflats during two seasons using inverse modelling: Aiguillon Cove and Brouage Mudflat, France. Estuar. Coast. Shelf Sci., v. 69, n. 1/2, p. 107-124, 2006.

DOLBETH, M.; MARTINHO, F.; LEITÃO, R.; CABRAL, H.; PARDAL, M. A. Feeding patterns of the dominant benthic and demersal fish community in a temperate estuary. J. Fish Biol., v. 72, n. 10, p. 2500-2517, 2008.

ELLIOTT, M.; DEWAILLY, F. The structure and components of European estuarine fish assemblages. Neth. J. Aquatic. Ecol., v. 29 , n. $3 / 4$, p. $397-417,1995$.

ELLIOTT, M.; WHITFIELD, A. K.; POTTER, I. C.; BLABER, S. J. M.; CYRUS, D. P.; NORDLI, E. F. G.; HARRISON, T. D. The guild approach to categorizing estuarine fish assemblages: a global review. Fish Fish., v. 8, p. 241-268, 2007. 
FIGUEIREDO, J. L.; MENEZES, N. A. Manual de peixes marinhos do sudeste do Brasil. II. Teleostei (1). São Paulo: Museu de Zoologia da Universidade de São Paulo, 1978. 110 p.

FIGUEIREDO, J. L.; MENEZES, N. A. Manual de peixes marinhos do sudeste do Brasil. III. Teleostei (2). São Paulo: Museu de Zoologia da Universidade de São Paulo, 1980. 90 p.

FIGUEIREDO, J. L.; MENEZES, N. A. Manual de peixes marinhos do sudeste do Brasil. VI. Teleostei (5). São Paulo: Museu de Zoologia da Universidade de São Paulo, 2000. 116 p.

FRANÇA, S.; PARDAL, M. A.; CABRAL, H. N. Mudflat nekton assemblages in the Tagus estuary (Portugal): distribution and feeding patterns. Sci. Mar., v. 73, n. 2, p. 591-602, 2008.

FRANÇA, S.; VINAGRE, C.; PARDAL, M. A.; CABRAL, H. N. Spatial and temporal patterns of benthic invertebrates in the Tagus estuary, Portugal: comparison between subtidal and an intertidal mudflat. Sci. Mar., v. 73, n. 2, p. 307-318, 2009.

FRANÇA, S.; VASCONCELOS, R. P.; FONSECA, V. F.; TANNER, S. E.; REIS-SANTOS, P.; COSTA, M. J.; CABRAL, H. N. Predicting fish community properties within estuaries: influence of habitat type and other environmental features. Estuar. Coast. Shelf Sci., v. 107, p. 22-31, 2012.

GARRISON, L. P.; LINK, J. S. Dietary guild structure of the fish community in the Northeast United States continental shelf ecosystem. Mar. Ecol. Prog. Ser., v. 202, p. 231-240, 2000.

HAJISAMAE, S.; IBRAHIM, S. Seasonal and spatial variations of fish trophic guilds in a shallow, semi-enclosed tropical estuarine bay. Environ. Biol. Fish., v. 82, n. 3, p. 251-264, 2008.

HAMMERSCHLAG, N.; OVANDO, D.; SERAFY, J. E. Seasonal diet and feeding habits of juvenile fishes foraging along a subtropical marine ecotone. Aquat. Biol., v. 9, n. 3, p. 279-290, 2010.

HARRISON, T. D; WHITFIELD, A. K. Fish trophic structure in estuaries, with particular emphasis on estuarine typology and zoogeography. J. Fish Biol., v. 81, n. 6, p. 2005-2029, 2012.

HINDELL, J. S.; JENKINS, G. P. Spatial and temporal variability in the assemblage structure of fishes associated with mangroves (Avicennia marina) and intertidal mudflats in temperate Australian embayments. Mar. Biol., v. 144, p. 85-395, 2004.

HURLBERT, S. H. The measurement of niche overlap and some relatives. Ecology, v. 59, n. 1, p. 67-77, 1978.

HYSLOP, E. J. Stomach contents analysis - a review of methods and their application. J. Fish Biol., v. 17, n. 4, p. 411-429, 1980.

INOUE, T.; SUDA, Y.; SANO, M. Food habits in the surf zone of a sandy beach at Sanrimatsubara, Fukuoka Prefecture, Japan. Ichthyol. Res., v. 52, n. 1, p. 9-14, 2005.

KELLNREITNER, F.; POCKBERGER, M.; ASMUS, H. Seasonal variation of assemblage and feeding guild structure of fish species in a boreal tidal basin. Estuar. Coast. Shelf Sci., v. 108 , p. $97-108,2012$.

KOPP, M. M.; DE SOUZA, V. Q.; COIMBRA, J. L. M.; LUZ, V. K.; MARINI, N.; OLIVEIRA, A. C. Melhoria da correlação cofenética pela exclusão de unidades experimentais na construção de dendogramas. Rev. Fac. Zoo. Vet. Agr., v. 14, n. 2, p. 46-53, 2007.

KREBS, C. J. Ecological methodology. New York: HarperCollins Publ., 1989. 624 p.
LABROPOULOU, M.; ELEFTHERIOU, A. The foraging ecology of two pairs of congeneric demersal fish species: importance of morphological characteristics in prey selection. J. Fish Biol., v. 50, n. 2, p. 324-340, 1997.

LEGUERRIERA, D.; DEGRÉA, D.; NIQUILA, N. Network analysis and inter-ecosystem comparison of two intertidal mudflat food webs (Brouage Mudflat and Aiguillon Cove, SW France). Estuar. Coast. Shelf Sci., v. 74, n. 3, p. 403-418, 2007.

LOBRY, J.; DAVID, V.; PASQUAD, S.; LEPAGE, M.; SAUTOUR, B.; ROCHARD, E. Diversity and stability of an estuarine trophic network. Mar. Ecol. Prog. Ser., v. 358, p. 13-25, 2008.

LUCZKOVICH, J. J.; WARD, G. P.; JOHNSON, J. C.; CHRISTIAN, R. R.; BAIRD, D.; NECKLES, H.; RIZZO, W. M. Determining the trophic guilds of fishes and macroinvertebrates in a seagrass food web. Estuaries, v. 25, n. 6 A, p. 1143-1163, 2002.

LUGENDO, B. R.; NAGELKERKEN, I.; VELDE, G. V.; MGAYA, Y. D. The importance of mangroves, mud and sand flats, and sea-grass beds feeding areas for juvenile fishes in Chwaka Bay, Zanzibar: gut content and stable isotope analyses. J. Fish Biol., v. 69, n. 6, p.1639-1661, 2006.

MACDONALD, J. S.; GREEN, R. H. Redundancy of variables used to describe importance of prey species in fish diets. Can. J. Fish. Aquat. Sci., v. 40, p. 635-637, 1983.

MARTINHO, F.; LEITÃO, R.; NETO, J. M.; CABRAL, H. N.; MARQUES, J. C.; PARDAL, M. A. The use of nursery areas by juvenile fish in a temperate estuary, Portugal. Hydrobiologia, v. 587, n. 1, p. 281-290, 2007.

MENEZES, N. A.; FIGUEIREDO, J. L. Manual de peixes marinhos do sudeste do Brasil. IV. Teleostei (3). São Paulo: Museu de Zoologia da Universidade de São Paulo, 1980. 96 p.

MENEZES, N. A.; FIGUEIREDO, J. L. Manual de peixes marinhos do sudeste do Brasil. V. Teleostei (4). São Paulo: Museu de Zoologia da Universidade de São Paulo, 1985. 105 p.

MOURÃO, J. S.; NORDI, N. Etnoecologia de pescadores artesanais do estuário do Rio Mamanguape, Paraíba, Brasil. Bol. Inst. Pesca, v. 29, n. 1, p. 9-17, 2003

OLIVEIRA, R. E. M. C. C.; PESSANHA, A. L. M. Fish assemblage along a morphodynamic continuum on three tropical beaches. Neotrop. Ichthyol., v. 12, n. 1, p. 165-175, 2014.

PAIVA, A. C. G.; CHAVES, P. T. C.; ARAÚJO, M. E. Estrutura e organização trófica da ictiofauna de águas rasas em um estuário tropical. Rev. Bras. Zool., v. 25, n. 4, p. 647-661, 2008.

PEREIRA, M. S.; ALVES, R. R. N. Composição Florística de um remanescente de Mata Atlântica na Área de Proteção Ambiental Barra do Rio Mamanguape, Paraíba, Brasil. Rev. Biol. Ciênc. Terra, v. 6, n. 1, p. 357-366, 2006.

PINKAS, L.; OLIPHONT, M. S.; IVERSON, I. L. K. Food habits of albacore, bluefin tuna, and bonito in California waters. California Fish Games, California Sacramento: State of California. Fish Bul., v. 152, p. 105, 1971.

ROCHA, M. S. P.; MOURÃO, J. S.; SOUTO, W. M. S.; BARBOZA, R. R. D.; ALVES, R. R. N. O uso dos recursos pesqueiros no estuário do Rio Mamanguape, estado da Paraíba, Brazil. Interciência, v. 33, n. 12, p. 903-909, 2008.

ROMESBURG, H. C. Cluster analysis for researchers. Morrisville: Lulu Press, 1984. 340 p. 
ROPER, D. S.; THRUSH, S. F.; SMITH, D. G. The influence of runoff on intertidal mudflat benthic communities. Mar. Environ. Res., v. 26, n. 1, p. 1-18, 1988.

ROSS, S. T. Resource partitioning in fish assemblages: a review of field studies. Copeia, v. 1986, p. 352-388, 1986.

SCHOENER, T. W. The controversy over interspecific competition. Am. Nat., v. 70, p. 586-595, 1982.

TSE, P.; NIP, T. H. M.; WONGCK, C. K. Nursery function of mangrove: A comparison with mudflat in terms of fish species composition and fish diet. Estuar. Coast. Shelf Sci., v. 80, n. 2, p. 235-242, 2008.

VASCONCELOS-FILHO, A. L.; NEUMANN-LEITÃO, S.; ESKINAZI-LEÇA, E.; OLIVEIRA, A. M. E.; PORTONETO, F. F. Hábitos alimentares de consumidores primários da ictiofauna do Sistema Estuarino de Itamaracá (Pernambuco - Brasil). Rev. Bras. Eng. Pesca, v. 4, n. 1, p. 21-31, 2009.

VIVIER, L.; CYRUS, D. P.; JERLING, H. L. Fish community structure of the St Lucia estuarine system under prolonged drought conditions and its potential for recovery after mouth breaching. Estuar. Coast. Shelf Sci., v. 86, n. 4, p. 568-579, 2010.
WANG, M.; HUANG, Z.; SHI, F.; WANG, W. Are vegetated areas of mangroves attractive to juvenile and small fish? The case of Dongzhaigang Bay, Hainan Island, China. Estuar. Coast. Shelf Sci., v. 85, n. 2, p. 208-216, 2009.

WILSON, J. P.; SHEAVES, M. Short-term temporal variations in taxonomic composition and trophic structure of a tropical estuarine fish assemblage. Mar. Biol., v. 139, n. 4, p. 787-796, 2001.

WOOTTON, R. J. Ecology of Teleost Fishes (Fish and Fisheries Series). Boston: Kluwer Academic Publishers, 1990. 386 p.

XAVIER, J. H. A.; CORDEIRO, C. A. M. M.; TENÓRIO, G. D.; DINIZ, A. F.; PAULO-JÚNIOR, E. P. N.; ROSA, R. S.; ROSA, I. L. Fish assemblage of the Mamanguape Environmental Protection Area, NE Brazil: abundance, composition and microhabitat availability along the mangrove-reef gradient. Neotrop. Ichthyol., v. 10, n. 1, p. 109-122, 2012. 